\title{
CHRZEŚCIJAŃSKA BAZYLIKA RZYMSKA - KONTYNUACJA CZY INNOWACJA?
}

28 października 312 r., w okolicach mostu mulwijskiego w Rzymie, Konstantyn nazwany później Wielkim, stoczył rozstrzygającą bitwę z Maksencjuszem o panowanie nad zachodnią częścią Imperium. Wkrótce potem z jego polecenia rozpoczęto budowę obiektu ofiarowanego jednej z gmin chrześcijańskich Rzymu - bazylikę na Lateranie, określaną w czasach jej powstania Basilica Constantiniana, obecnie pod wezwaniem św. Jana (il. 1) ${ }^{1}$. Stała się ona pierwowzorem typu budowli, który na zachodnich terytoriach cesarstwa od czasów zwycięstwa Konstantyna nad Maksencjuszem w 312 r., a we wschodnich prowincjach cesarstwa od 324 r., tzn. od pokonania Licyniusza - stał się podstawowym typem architektonicznym dla obiektów, w których gromadzili się chrześcijanie. W niniejszym artykule nie będziemy się zajmować ustaleniem momentu, w którym bazyliki chrześcijańskie zaczęto wykorzystywać jako miejsca sprawowania kultu, a jedynie postaramy się zarysować jeden z podstawowych problemów odnoszących się do bazyliki laterańskiej, mianowicie problem oryginalności jej formy. Jego rozwiązanie może pozwoli nam odpowiedzieć na zasadnicze pytanie zawarte w tytule niniejszego szkicu: czy forma bazyliki chrześcijańskiej jest kontynuacją istniejących wcześniej tradycji architektoniczno-artystycznych, czy może należałoby ją uznać za twór oryginalny.

Bazylika ta, w najwcześniejszym wzmiankującym ją źródle, czyli w Liber Pontificalis, określana jest jako Basilica Constantiniana2. Struktura tej nazwy

*Dr hab. Zygmunt Kalinowski - Muzeum Pierwszych Piastów na Lednicy; e-mail: zygkali@ poczta.onet.pl.

${ }^{1}$ Dokładne datowanie bazyliki laterańskiej, w oparciu o dzisiejszy stan badań, nie jest możliwe, ale niewątpliwie powstała w czasach Konstantyna. Za wczesnym datowaniem rozpoczęcia budowy (312/313) optował R. Krautheimer (The Constantinian Basilica, DOP 21:1967, 119); później dopuszczając jeszcze inne daty 318, 329 a nawet 335 (R. Krautheimer - S. Corbett - A.K. Frazer, Corpus Basilicarum Christianarum Romae, V, Città del Vaticano 1977, 90). Podobnie datuje ten obiekt Ch. Pietri (Roma Christiana. Recherches sur l'Église de Rome, son organisation, sa politique, son idéologie de Miltiade à Sixte III (311-440), Paris 1976, 5-9), określając czas jej budowy na pierwsze 15 lat panowania Konstantyna. Wnikliwą analizę tego problemu przeprowadziła B. Iwaszkiewicz-Wronikowska, Domus - Ecclesia - Aedes. Powstawanie światyni chrześcijańskiej. Powstawanie światyni chrześcijańskiej, w: SymKaz I, Lublin 1998, 24nn.

${ }^{2}$ Por. LP 34, 9-10, ŹMT 74 [wyd. łacińsko-polskie, opr. M. Ożóg - H. Pietras, thum. P. Szew- 
jest identyczna jak nazw: Basilica Porcia, Basilica Aemilia, Basilica Ulpia, Basilica Severiana. Idąc dalej tym tropem można by w niej widzieć obiekt o podobnych znaczeniach społecznych jak wymienione wyżej bazyliki foralne: to dar cesarza dla społeczności Rzymu. Różnica, jaka rysuje się pomiędzy bazylikami przedkonstantyńskimi a konstantyńska, jest jednak znaczna. Te pierwsze wznoszone były w centrum Rzymu jako swoista demonstracja potęgi cesarza i były inwestycją przeznaczoną dla użytku całego ludu rzymskiego, podczas gdy Basilica Constantiniana była obiektem wzniesionym na przedmieściach miasta, na prywatnym terenie rodziny cesarskiej i przekazana została w użytkowanie chrześcijanom, czyli niewielkiej społeczności, która na przełomie III i IV w. stanowiła w Rzymie zdecydowaną mniejszość 3 .

Jak wyglądała budowla, która - jak będziemy starali się dowieść - była jednym z najważniejszych obiektów architektonicznych $w$ dziejach cywilizacji europejskiej? Składała się z kilku zasadniczych części, z których każda manifestowała swą obecność charakterystyczną formą, rozpoznawalną zarówno w jej bryle, jak i w jej wnętrzu. Jej korpus, wzniesiony na rzucie wydłużonego prostokąta, tworzyło pięć naw: główna, najwyższa; bezpośrednio flankujące ją wzdłuż długich boków dwie nawy boczne, niższe i węższe, ale o tej samej długości; oraz niższe od nich i nieco krótsze kolejne dwa trakty naw bocznych, zakończone (po tej samej stronie co absyda) niewielkimi przybudówkami, nieznacznie wystającymi poza lica wzdłużnych ścian tych naw. Nawa główna zakończona była półkolistą apsydą o średnicy prawie równej jej szerokości. Niewiele możemy powiedzieć o drugim krańcu korpusu nawowego, bowiem podczas prac archeologicznych nie natrafiono na żadne relikty tej części budowli pochodzące z jej najwcześniejszej fazy. Przypuszcza się, poprzez analogię do kościołów nieznacznie późniejszych, że do wnętrza prowadziło trzy lub pięć wejść, poprzedzonych niewielkim przedsionkiem. Trudno orzec czy bazylika ta posiadała atrium, choć w kościołach 2. poł. IV w. atrium pojawia się jako rozwiązanie kanoniczne.

Spośród istniejącego zbioru potencjalnych antenatów architektonicznych bazyliki chrześcijańskiej, dwa typy budowli - poprzez swoje podobieństwo

czyk, SCL 9], Kraków 2014, 67: „Huius temporibus fecit Constantinus Augustus basilicas istas quas et ornavit: Basilicam Constantinianam, ubi posuit ista dona: fastidium argenteum battutilem, qui habet in fronte Salvatorem sedentem in sella, in pedibus V, pens. lib. CXX, et XII apostolos qui pens. sing. in quinos pedibus libras nonagenas, cum coronas argento purissimo; item a tergo respiciens in absida, Salvatorem sedentem in throno, in pedibus V, ex argento purissimo, pens. lib. CXL, et angelos IIII ex argento, qui pens. sing. in pedibus V lib. CV, cum gemmis alabandenis in oculos, tenentes astas; fastidium ipsum pens. lib. III XXV, ex argento dolaticium".

${ }^{3}$ Przypuszcza się, iż w III w. w Rzymie mieszkało ok. 50 tys. chrześcijan - por. ks. A. Luft, Kościoly pierwszych chrześcijan, w: Eucharystia pierwszych chrześcijan. Ojcowie Kościoła nauczajq o Eucharystii, wyb. i opr. ks. M. Starowieyski, OŻ 7, Kraków 1987, 53. Całą populację Rzymu w tym okresie szacuje się na ok. 1.250 .000 mieszkańców - por. W.J. Oates, The Population of Rome, CPh 29 (1934) 101-116. 
formalne - zwracają w sposób szczególny naszą uwagę: bazylika foralna i cesarska sala audiencyjna. Bazylika foralna, jeden z podstawowych typów publicznych budowli rzymskich. Najstarszy ze znanych nam przykładów bazylik rzymskich to pięcionawowa Basilica Porcia, wzniesiona przez Marka Porcjusza Katona (Starszego) w 184 r. prz. Chr. Jej lokalizacja nie została potwierdzona archeologicznie, ale najprawdopodobniej budowla wznosiła się na zachód od budynku Kurii. Późniejsze bazyliki, bardzo do niej podobne, to też obiekty pięcionawowe $z$ wyniesioną nawą główną i niższymi nawami bocznymi. Wszystkie wielkie bazyliki rzymskie: Porcia, Julia, Aemilia, Ulpia (il. 2) wznoszone były w najbardziej eksponowanych miejscach Rzymu przez wybitnych obywateli tego miasta, a od II w. w zasadzie tylko przez cesarzy $^{4}$. Były darem panującego dla społeczności Rzymu, uświetniającym jego panowanie. Ich budowa, podobnie jak budowa term czy forów, obliczona była nie tylko na realizację cesarskich urbanistyczno-architektonicznych ambicji kreatorskich, ale była również narzędziem budowania dobrego wizerunku cesarza jako władcy dbającego o swoich poddanych i rozwój miasta. W rzeczywistości bazylika $\mathrm{i}$ forum stały się w czasach cesarstwa podstawowymi publicznymi przestrzeniami miasta, w których tętniło życie społeczne Rzymu, przestrzeniami wypełnionymi ludźmi, którzy postrzegali je jako dobro wspólne dostępne każdemu obywatelowis.

Najsłynniejszą bazyliką foralną w czasach Konstantyna była trajańska Basilica Ulpia (il. 3). Ten potężnych rozmiarów obiekt - wspaniałe dzieło architektury, zaprojektowane prawdopodobnie przez Apollodorosa z Damaszku - wzniesiony został po zachodniej stronie Forum Trajana. Bazylika była elementem potężnego kompleksu urbanistycznego, na który składały się (wymieniając od wschodu): forum poprzedzone łukiem triumfalnym, ujęte od południa i północy monumentalnymi eksedrami, z konnym posagiem Trajana w centrum, dalej bazylika zakończona na krótszych bokach podobnie jak forum eksedrami oraz budynki bibliotek i wyrastający między nimi potężny monostyl ${ }^{6}$. Architektura bazyliki, dominującej swoją skalą nad całym kompleksem, wzbogacona została wzmiankowanymi już eksedrami, których funkcje wywoływały jednoznaczne asocjacje odnoszące się do pojęcia władzy, bowiem w jednej orzekano wyroki sądowe, w drugiej sprawowany był kult cesarski.

Czy w bazylice tej możemy upatrywać pierwowzoru tego, co w kategoriach typologicznych określić można jako rzymską bazylikę chrześcijańską?

${ }^{4}$ Por. J.B. Ward-Perkins, Constantine and the Origins of the Christian Basilica, „Papers of the British School at Rome" 22 (1954) 69-90.

${ }^{5}$ Por. J. Carcopino, Życie codzienne w Rzymie w okresie rozkwitu Cesarstwa, tłum. M. Pąkcińska, Warszawa 1960, 12-19; P. Veyne, Cesarstwo Rzymskie; w: Historia życia prywatnego, t. 1: Od Cesarstwa Rzymskiego do roku tysięcznego, red. P. Veyne, tłum. K. Arustowicz - M. Rostworowska, Wrocław 1998, 178-179.

${ }^{6}$ Por. J.B. Ward-Perkins, Roman Architecture, London 1988, 42-45. 
Odpowiedź tylko z pozoru wydaje się prosta. Pobieżna analiza formy wykaże oczywiście duże podobieństwa architektoniczne między tymi obiektami: oba to pięcionawowe bazyliki z charakterystycznym sposobem oświetlenia naw bocznych i z identycznym systemem artykulacji wnętrza poprzez zastosowanie ciąóo kolumn. Gdy jednak weźmiemy pod uwagę funkcję, jaką miały pełnić, podobieństwa nie są już takie jednoznaczne. Bazylika foralna przeznaczona była do przebywania w niej ludzi (il. 4), podczas gdy chrześcijańska - do gromadzenia ich. Pierwsza $z$ tych funkcji nie wymagała żadnych zabiegów architektonicznych organizujących czy hierarchizujących przestrzeń, podczas gdy druga musiała wprowadzić rozwiązania umożliwiające uporządkowanie masy ludzi gromadzących się w jej wnętrzu (il. 5). Wnętrze pierwszej przystosowane było do ruchu i przygotowane na dynamiczne przemieszczanie się ludzi - posiadało dziewięć wejść od wschodu (dłuższy bok) i dwa wejścia od zachodu, gwarantując możliwość szybkiego przepływu odwiedzających. Bazylika chrześcijańska z maksymalnie trzema wejściami na krótszym boku, przystosowywała swoje wnętrze do funkcji o zupełnie odmiennym charakterze. Miała zapewnić utrzymanie porządku, wyraźny hierarchiczny podział przestrzeni i sprzyjać koncentracji uwagi na dominancie, jaką stanowiła apsyda $\mathrm{z}$ tronem biskupa i prawdopodobnie mensa, na jej tle $\mathrm{f}^{7}$. Dla naszych rozważań, próbujących jedynie nakreślić problem recepcji formy, nie będzie miało większego znaczenia czy przyjmiemy tradycyjny punkt widzenia upatrujący w tych wczesnych bazylikach chrześcijańskich miejsce sprawowania eucharystii, czy wyeliminujemy taką możliwość. Skoro budowle te służyć miały wybranej społeczności, której wyróżnikiem jest wyznawana religia, to spotkania w nich organizowane należałoby uznać za religijne, choć być może, jak przyjmują niektórzy badacze, nie od początku kultowe ${ }^{8}$. Tak czy inaczej gromadzenie w nich ludzi wymagało uporządkowania przestrzeni i stworzenia strefy dla przewodniczącego zgromadzenia. Tymczasem wnętrze bazyliki foralnej było z natury swej wnętrzem wolnym i demokratycznym, bowiem nie przypisywało nikomu konieczności zajęcia określonego miejsca, ani też

${ }^{7}$ Problem lokalizacji stołu/mensy we wczesnych kościołach budzi do dziś kontrowersje. Jednak już Euzebiusz z Cezarei (HE VII 15) pisał o „ołtarzu” w odniesieniu do czasów po Walerianie, a więc w 2. poł. III w. Za mensą w najwcześniejszych bazylikach rzymskich opowiadają się m.in. R. Krautheimer, Early Chrystian and Byzantine Architecture, Harmondsworth 1986 ${ }^{4}$, 48; F. Deichmann, Archeologia chrześcijańska, tłum. E. Jastrzębowska, Warszawa 1994, 68; E. Jastrzębowska, Sztuka wczesnochrześcijańska, Kraków 2008, 67-68; H. Brandenburg, Die frühchridtlichen kirchen in Rom: vom 4. Bis zum 7. Jahrhundert, Milano 2004, 26.

${ }^{8}$ Za wykorzystaniem bazyliki laterańskiej do sprawowania eucharystii zdecydowanie opowiada się Krautcheimer (The Constantinian Basilica, s. 121; Three Christian Capitals. Topography and Politics, Berkeley - London 1983, 18). Przeciw tej tezie wystapiła B. Iwaszkiewicz-Wronikowska (Domus - Ecclesia - Aedes, s. 29). Rozbudowaną argumentację za traktowaniem tego obiektu od początku jako kultowego przedstawiłem w: Z. Kalinowski, Orient und Rom, okcydentalność i orientalność kościołów antycznych. Architektura jako język polityki i teologii, Poznań 2013, 31-123. 
nie określało w żaden sposób hierarchii jego poszczególnych części. Jej przestrzeń była jednocześnie przestrzenią dynamiczną, zakładającą ruch i możliwość swobodnego przemieszczania się w niej.

Wiemy, że na długo przed Konstantynem chrześcijanie skodyfikowali sposób gromadzenia się w trakcie swoich spotkań kultowych ${ }^{9}$. Czy zatem wolna od orientacji i demokratyczna z natury przestrzeń bazyliki foralnej mogła być przez nich wykorzystywana na potrzeby gminnych spotkań kultowych? Użycie w bazylice chrześcijańskiej apsydy na jej krótszym końcu i umieszczenie wejścia lub wejść w przeciwległej ścianie, było zabiegiem, jak sądzę, nieprzypadkowym, wywołanym chęcią czy może raczej koniecznością uporządkowania i zhierarchizowania jej przestrzeni. Zabiegu tego dokonano poprzez zastosowanie określonych form architektonicznych i wykorzystanie asocjacji, które użycie tych form wywoływały ${ }^{10}$.

Obiektem, który dostarczał doskonałych rozwiązań formalnych, przy tym nasyconych określoną symboliką, była cesarska sala audiencyjna. Ze znanych Konstantynowi obiektów wymienić należałoby co najmniej dwa: Aulę Palati$n a$ w Trewirze wybudowana przez Konstancjusza Chlorusa, a być może ukończoną przez Konstantyna (il. 6), oraz rzymską bazylikę Maksencjusza, którą Konstantyn nie tylko ukończył, ale przede wszystkim zmienił (il. 7) ${ }^{11}$.

Tradycja budowy sal audiencyjnych, o wypracowanym schemacie architektonicznym, była na początku IV w. już bardzo ugruntowana budową wcześniejszych obiektów, wśród których należałoby wymienić chociażby Aule Regia z zespole pałacowym Domicjana na Palatynie (il. 10). Identyczne funkcje tych trzech wymienionych wyżej obiektów pozwalają na zdefiniowanie ich programów. Ich podstawowym zadaniem było stworzenie odpowiednich warunków zapewniających określone relacje, jakie zachodziły pomiędzy cesarzem a osobami, które dostąpiły zaszczytu spotkania z nim. Pomijając kwestię oczywistego w takich sytuacjach przepychu i skali, skoncentrujmy się na zasadniczych elementach przestrzeni takiego wnętrza z próbą określenia

${ }^{9}$ Opis spotkań eucharystycznych nie pozostawia wątpliwości, że lokalizacja poszczególnych grup w kościele była ściśle określona. Najstarsze instrukcje pojawiają się już w Didache, które stanowiły podstawę do opracowania części Konstytucji Apostolskich (II 57, 1-21). Por. M. Aquiliana, Msza pierwszych chrześcijan, thum. P. Ahmad, Gdańsk 2009, 60-62.

${ }^{10}$ Warto zauważyć, że wśród bazylik przedchrześcijańskich dominował typ, w którym główne wejścia poprzedzone portykiem znajdowały się na dłuższym boku, by umożliwić swobodniejszy dostęp do wnętrza. Typ ten szczegółowo opisany przez Witruwiusza (De architectura V 1) za Ward-Perkinsem nazywam tutaj ,,witruwiańskim”. Por. Ward-Perkins, Constantine and the Origins of the Christian Basilica, s. 69-90, spec. 71-73. Obok „witruwiańskiego” Ward-Perkins (tamże, s. 73-74) wyróżnił jeszcze typ „hellenistyczny” ustawiany krótszym bokiem do forum, z wejściem jedynie na tej ścianie.

${ }^{11} \mathrm{O}$ zabiegach Konstantyna w tej materii, por. E. Jastrzębowska, Maksencjusz: ostatni czy pierwszy twórca rzymskiej architektury późno antycznej, w: Bitwa przy moście mulwijskim. Konsekwencje, red. Z. Kalinowski - D. Próchniak, Poznań 2014, 203-220. 
ich roli. Obiekty takie to obszerne sale (w okresie późnego cesarstwa mówić możemy o gigantomanii), których skala gwarantowała realizację ważnej części audiencji, czyli maksymalne wydłużenie drogi dojścia przed oblicze imperatora. Osiagano to m.in. poprzez umieszczenie tronu cesarskiego na jednym krańcu, a wejścia na drugim. Stworzona w ten sposób oś jednoznacznie wytyczała kierunek postrzegania całej przestrzeni ${ }^{12}$. Drugim zasadniczym elementem architektonicznym cesarskiej sali audiencyjnej była potężna nisza lub apsyda na krótszym końcu, która wydzielała miejsce dla tronu cesarskiego. Ta monumentalna sferyczna przestrzeń wytyczona krzywizną ściany apsydy i czaszą konchy nadawała jej cech niezwykłości, bo też osoba, która w niej się pojawiała, miała być postrzegana jako postać niezwykła.

Przebudowę przez Konstantyna wnętrza Bazyliki Maksencjusza, polegającą na wprowadzeniu drugiej apsydy na osi nawy bocznej - apsydy, w której ustawiono tron cesarski, oraz budowę drugiego wejścia na wprost tej apsydy, thumaczy fakt ustawienia w pierwotnej apsydzie wielkiego posagu cesarza. Zabieg ten odwoływał się w swojej ukrytej symbolice do aktu deifikacji Konstantyna, stąd też asocjacje, jakie w bazylice laterańskiej wywoływała potężna apsyda $z$ ustawionym na jej tle tronem, były w rzymskiej rzeczywistości IV w. oczywiste i jednoznacznie odnosiły się do osoby cesarza, jego potężnej władzy i najwyższego autorytetu.

Wydaje się, że zastosowanie w rzymskiej bazylice chrześcijańskiej apsydy miało trzy zasadnicze cele. Po pierwsze: poprzez ustawienie na tle apsydy tronu biskupa, użyczało biskupowi Rzymu czyli liderowi coraz bardziej rosnącej w siłę niewielkiej grupy religijnej, autorytetu najwyższego z możliwych - autorytetu cesarskiego z wszelkimi konsekwencjami tego zjawiska, z których najważniejszym było szerzenie idei rodzącego się właśnie nowego ładu religijnego i relacji między państwem a Kościołem.

Po drugie: porządkowało przestrzeń, czyli określało kierunek od wejścia do apsydy jako kierunek percepcji wszelkich zjawisk, jakie na jej tle się rozgrywały. Po trzecie: wprowadzało hierarchię przestrzeni, niezbędną w przypadku organizacji spotkań, w których uczestniczyły setki osób.

Bazylika laterańska wraz z innymi chrześcijańskimi realizacjami Konstantyna zaproponowała pewien typ architektoniczny, który emanował cechą charakterystyczną dla całej kultury rzymskiej, a którą określić można krótko jako wielką umiejętność tworzenia nowych jakości przez kompilację istniejących już rozwiązań. Warto w tym momencie dodać, iż IV-wieczna kultowa architektura chrześcijańska poszukując swego „właściwego” oblicza, powołała do życia dziś już zapomniane rozwiązania, które okazały się nieprzekonywujące

${ }^{12} \mathrm{~W}$ bazylice laterańskiej zapewne celowo zastosowano układ longitudinalny z wejściem na krótkim boku, by osiagnąć cel, jakim była wydłużona, kierunkowa przestrzeń z koncentracją uwagi na wnętrzu apsydy. W większości rzymskich bazylik foralnych pojawiał się układ transwersalny z wejściami na długich bokach. 
w konfrontacji z bazyliką. Takie obiekty jak kościoły Apostołów i św. Wawrzyńca w Mediolanie (il. 11 i 12), czy kościół św. Gereona w Kolonii (il. 13) testowały inne rozwiązania formalne, choć zasadniczy element przestrzeni kultowej, jakim jest apsyda, był w nich obecny.

Czy można zatem rozstrzygnąć wątpliwość zawartą w tytule tego artykułu? Wydaje się, że odpowiedź na tak zarysowane pytanie może być różna w zależności od tezy wyjściowej opisującej zjawisko powstania bazyliki chrześcijańskiej. Dla szukającego tradycji w jej obliczu, będzie ona zawsze „tylko" pewną modyfikacją istniejących wcześniej rozwiązań bazylikalnych. Dla badacza analizującego proces twórczy, który nigdy nie odbywa się w próżni kulturowej, bazylika chrześcijańska będzie genialnym tworem, który w sposób oryginalny połączył w jednym obiekcie długą tradycję architektoniczną z nowatorskim jej przetworzeniem, w celu nadania jej nowych cech funkcjonalnych i ideowych. Wykorzystując czytelne asocjacje symboliczne poprzez zastosowanie znanych form, stała się bazylika chrześcijańska nie tylko nowym funkcjonalnym obiektem kultowym, ale również wyrazistym przekazem ideowym.

Jednym z zasadniczych pojęć rzymskiej estetyki była zasada decorum. Wydaje się, iż 1700-letnia tradycja budowy bazylik chrześcijańskich jest wystarczająco długa, by uznać stosowność doboru formy do treści, jakimi miała bazylika chrześcijańska emanować. Jej forma, przy czytelnych tradycyjnych wzorcach okazała się niezwykle trafna i na tyle właściwa, że przetrwała w niezmienionej formie podstawowego programu architektonicznego do dziś.

\section{EARLY CHRISTIAN ROMAN BASILICA - CONTINUITY OR INNOVATION?}

\section{(Summary)}

The article is an attempt to arouse a discussion about the originality of the design of Roman Christian basilica. The author deals with the form of basilica Constantiniana and strives to reconstruct its architectonic and functional programme. Formal borrowings from forum basilicas and imperial audience halls have been indicated. The formal adoption from those objects has been justified in two ways. The idea of acquiring the scale and inside arrangement from forum basilicas stemmed from the similarity of function. In turn, hierarchical order of the interior was achieved due to an apse moved to the shorter side with the entrances on the opposite one; such a compositional solution was taken from imperial basilicas. It was aimed to focus an attention of the faithful at actions which were taking place against the apse as well as at the bishop himself. The apse's symbolic significance 
raised the rank of a building, thus granting a bishop the emperor's authority. The development of Roman Christian basilica - understood as such process - turned this object into original architectonic creation. It joined ingeniously the function of gathering the faithful (procedure unknown to the prior Roman cult architecture) with the visualisation of the symbolism of power - of a bishop, in this case - emanating from the form of the apse and from the structure of the building, both derived from imperial basilicas.

Key words: origins of Early Christian basilica, basilica Constantiniana.

Słowa kluczowe: geneza formy bazyliki wczesnochrześcijańskiej, basilica Constantiniana.

\section{BIBLIOGRAFIA}

\section{Źródła}

Constitutiones Apostolorum, wyd. grecko-polskie, w: Konstytucje Apostolskie oraz Kanony Pamfilosa z apostolskiego synodu w Antiochii, Prawo kanoniczne świętych Apostotów, Kary świętych Apostołów dla upadtych, Euchologion Serapiona, układ i oprac. A. Baron - H. Pietras, thum. S. Kalinkowski, ŹMT 42 = SCL 2, Kraków 2007, 1-293. Eusebius CAeSARIENSIS, Historia ecclesiastica, wyd. grecko-polskie: Euzebiusz z Cezarei, Historia kościelna, red. H. Pietras, tłum. A. Caba na podstawie thum. A. Lisieckiego, ŹMT 70, Kraków 2013.

Liber Pontificalis (1-96), wyd. łacińsko-polskie: Księga Pontyfików (1-96), oprac. M. Ożóg - H. Pietras, tłum. P. Szewczyk (1-90) - M. Jesiotr (91-96), ŹMT $74=$ SCL 9, Kraków 2014.

\section{Opracowania}

Aquiliana M., Msza pierwszych chrześcijan, tłum. P. Ahmad, Gdańsk 2009.

Brandenburg H., Die frühchridtlichen kirchen in Rom: vom 4. Bis zum 7. Jahrhundert, Milano 2004.

Carcopino J., Życie codzienne w Rzymie w okresie rozkwitu Cesarstwa, thum. M. Pąkcińska, Warszawa 1960.

Deichmann F., Archeologia chrześcijańska, thum. E. Jastrzębowska, Warszawa 1994.

Iwaszkiewicz-Wronikowska B., Domus - Ecclesia-Aedes. Powstawanie światyni chrześcijańskiej, w: SymKaz I, Lublin 1998, 11-45.

JASTRZĘBOwSKA E., Maksencjusz: ostatni czy pierwszy twórca rzymskiej architektury późno antycznej, w: Bitwa przy moście mulwijskim. Konsekwencje, red. Z. Kalinowski D. Próchniak, Poznań 2014, 203-220.

JASTRZĘBOwska E., Sztuka wczesnochrześcijańska, Kraków 2008.

KalinowsKi Z., Orient und Rom, okcydentalność i orientalność kościołów antycznych. Architektura jako język polityki i teologii, Poznań 2013.

Krautcheimer R., Three Christian Capitals. Topography and Politics, Berkeley - London 1983. 
Krautheimer R. - Corbett S. - Frazer A.K., Corpus Basilicarum Christianarum Romae, V, Città del Vaticano 1977.

Krautheimer R., Early Chrystian and Byzantine Architecture, Harmondsworth $1986^{4}$.

Krautheimer R., The Constantinian Basilica, DOP 21 (1967) 115-140.

Luft A., Kościoły pierwszych chrześcijan, w: Eucharystia pierwszych chrześcijan. Ojcowie Kościoła nauczajq o Eucharystii, wyb. i opr. ks. M. Starowieyski, OŻ 7, Kraków 1987, 52-70.

OAtes W.J., The Population of Rome, CPh 29 (1934) 101-116.

PIETRI Ch., Roma Christiana. Recherches sur l'Église de Rome, son organisation, sa politique, son idéologie de Miltiade à Sixte III (311-440), Paris 1976.

Veyne P., Cesarstwo Rzymskie; w: Historia życia prywatnego, t. 1: Od Cesarstwa Rzymskiego do roku tysięcznego, red. P. Veyne, thum. K. Arustowicz - M. Rostworowska, Wrocław 1998, 17-222.

Ward-Perkins J.B., Constantine and the Origins of the Christian Basilica, „Papers of the British School at Rome" 22 (1954) 69-90.

Ward-Perkins J.B., Roman Architecture, London 1988.

\section{ANEKS}

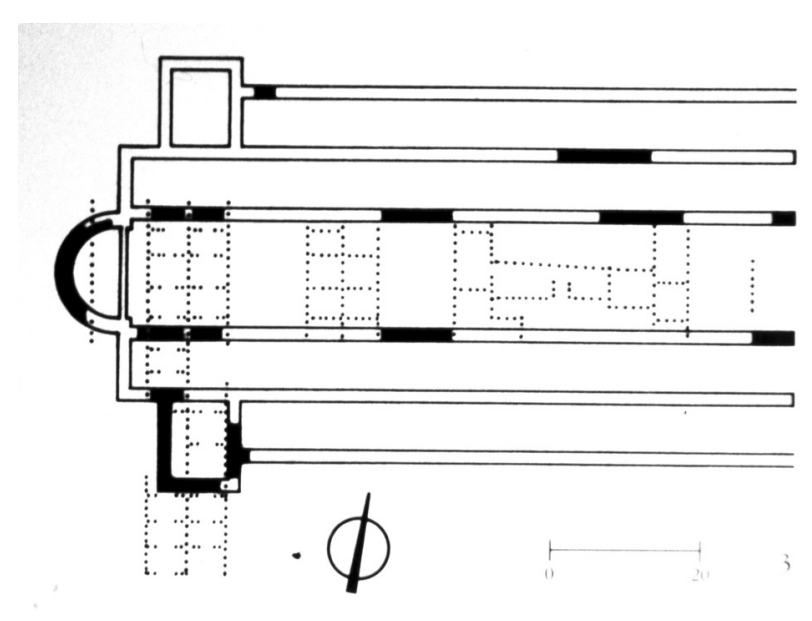

Il. 1. Rzym, bazylika Constantiniana na Lateranie, po 313 (za: B. Filarska, Archeologia chrześcijańska, Warszawa 1999, il. 41a). 


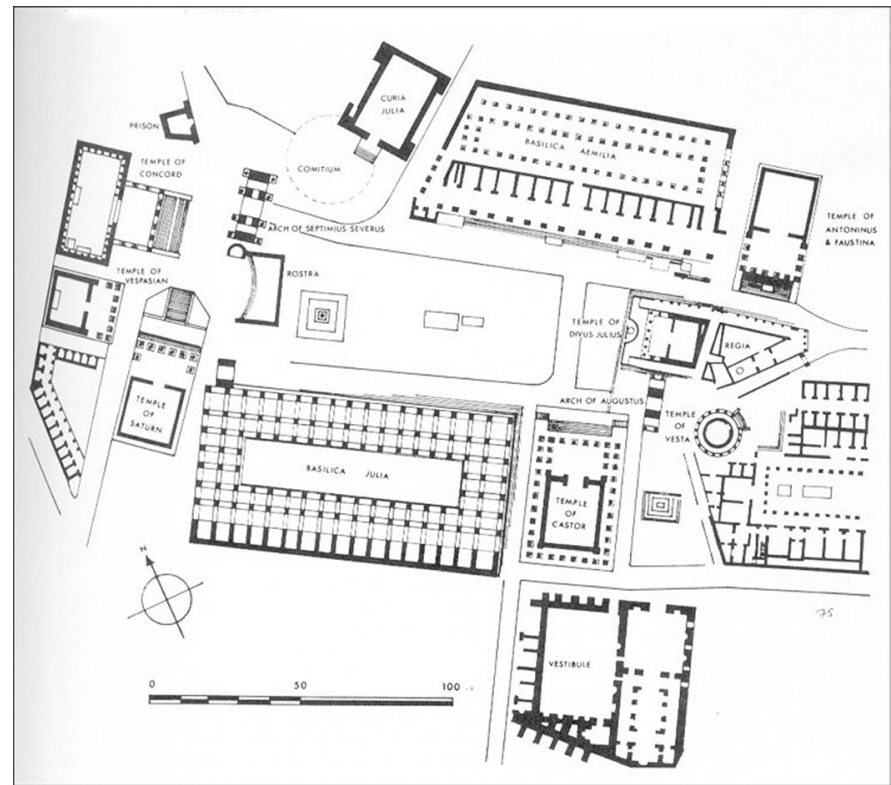

Il. 2. Rzym, Forum Romanum z bazylikami Aemilia i Julia (za: J.B. Ward-Perkins, Roman Architecture, London 1988, fig. 69).

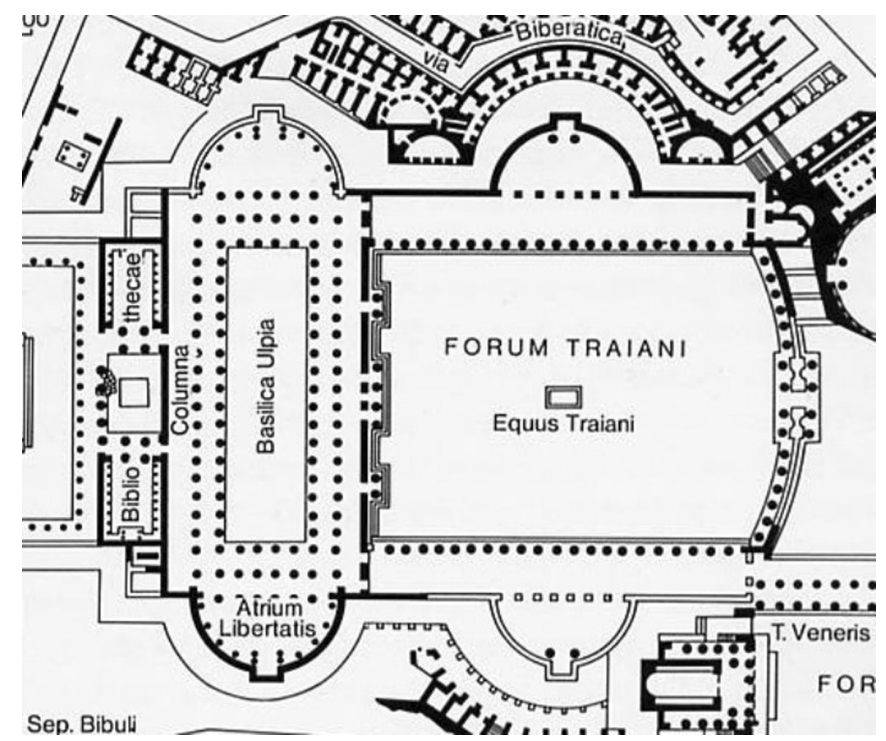

Il. 3. Rzym, bazylika Ulpia na Forum Trajana (za: J.B. Ward-Perkins, Roman Architecture, London 1988, fig. 67). 


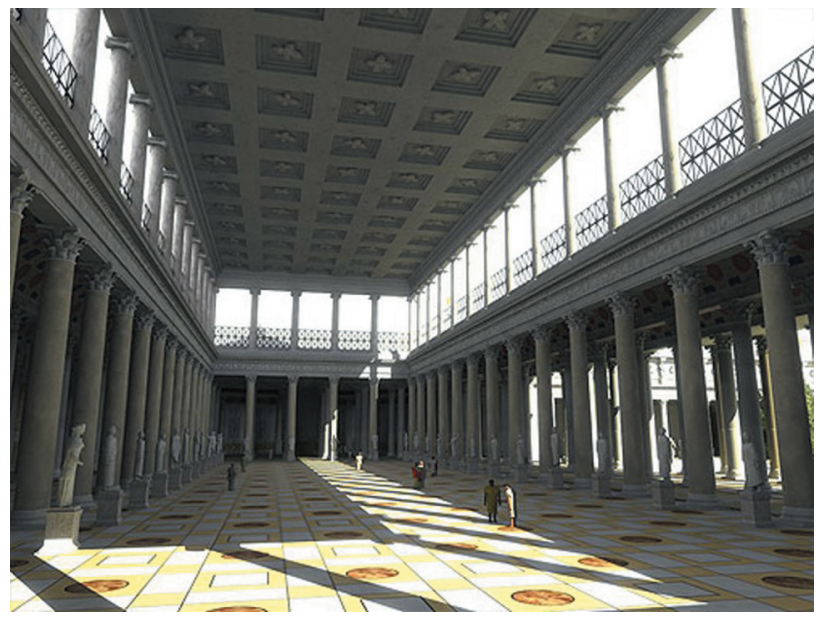

Il. 4. Rzym, rekonstrukcja komputerowa wnętrza bazyliki Ulpia na Forum Trajana, źródło: http://www.proun-game.com/ForumTrajani/Basilica.html (data dostępu 25.08.2012).

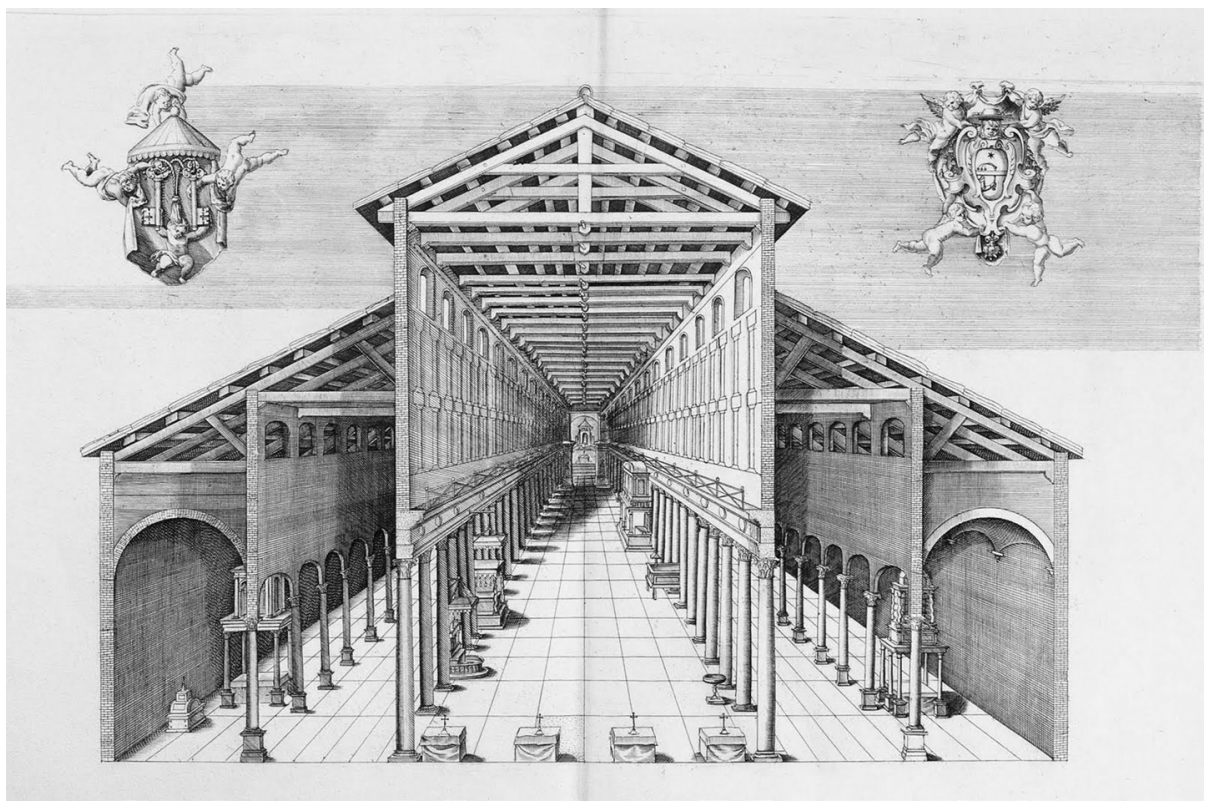

Il. 5. Rzym, wnętrze bazyliki św. Piotra na Watykanie wg szkicu Jacopo Grimaldi (1619) (MS Barberini, lat. 2733, fols. 104v-105r), (za: J. Snyder, Medieval Art. Painting Sculpture Architecture $4^{\text {th }}-14^{\text {th }}$, New York 1989, il. 28). 


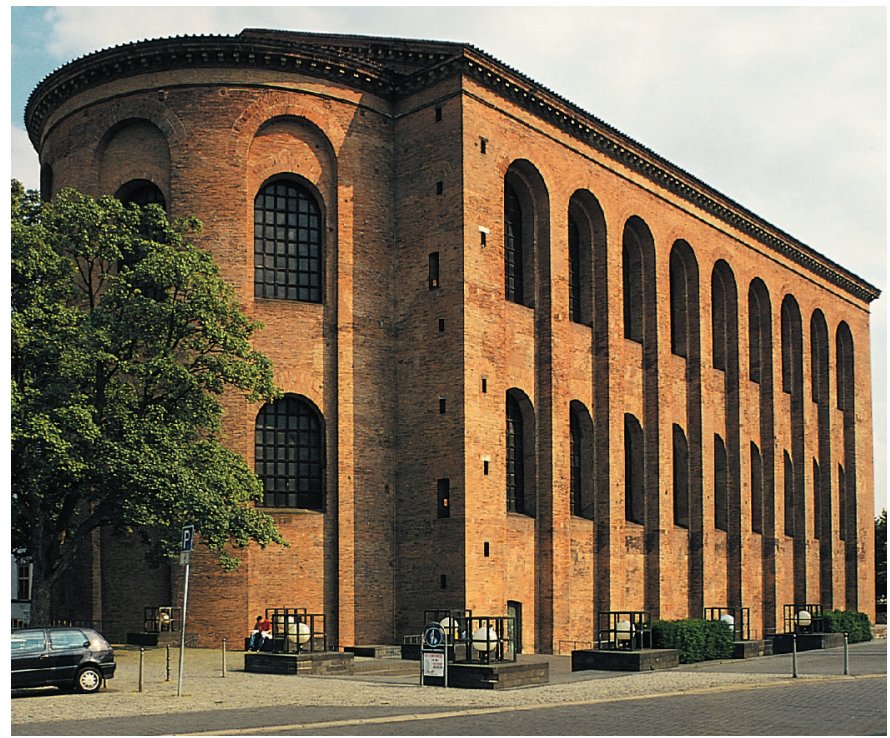

Il. 6. Trewir, Aula Palatina, ok. 310, stan obecny (widok z zewnątrz) (fot. Z. Kalinowski).

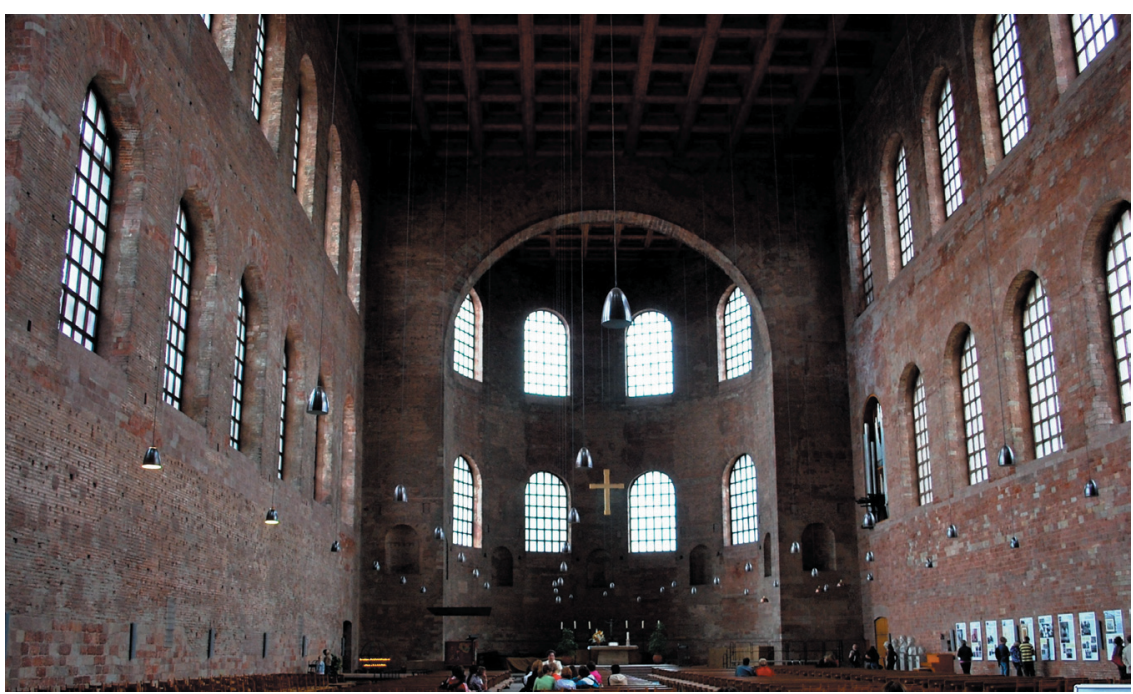

Il. 7. Trewir, Aula Palatina, ok. 310, stan obecny (widok wnętrza) (fot. Z. Kalinowski). 


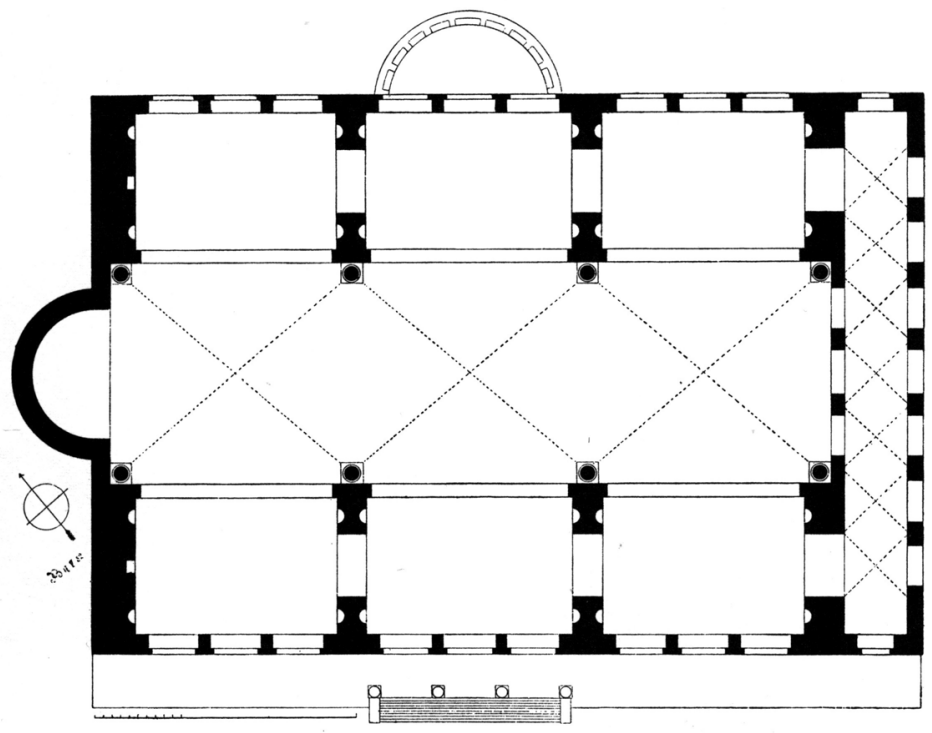

Il. 8. Rzym, bazylika Maksencjusza, ok. 313 (za: K.T. Kraus, Das römische Weltreich, Berlin 1967, fig.15).

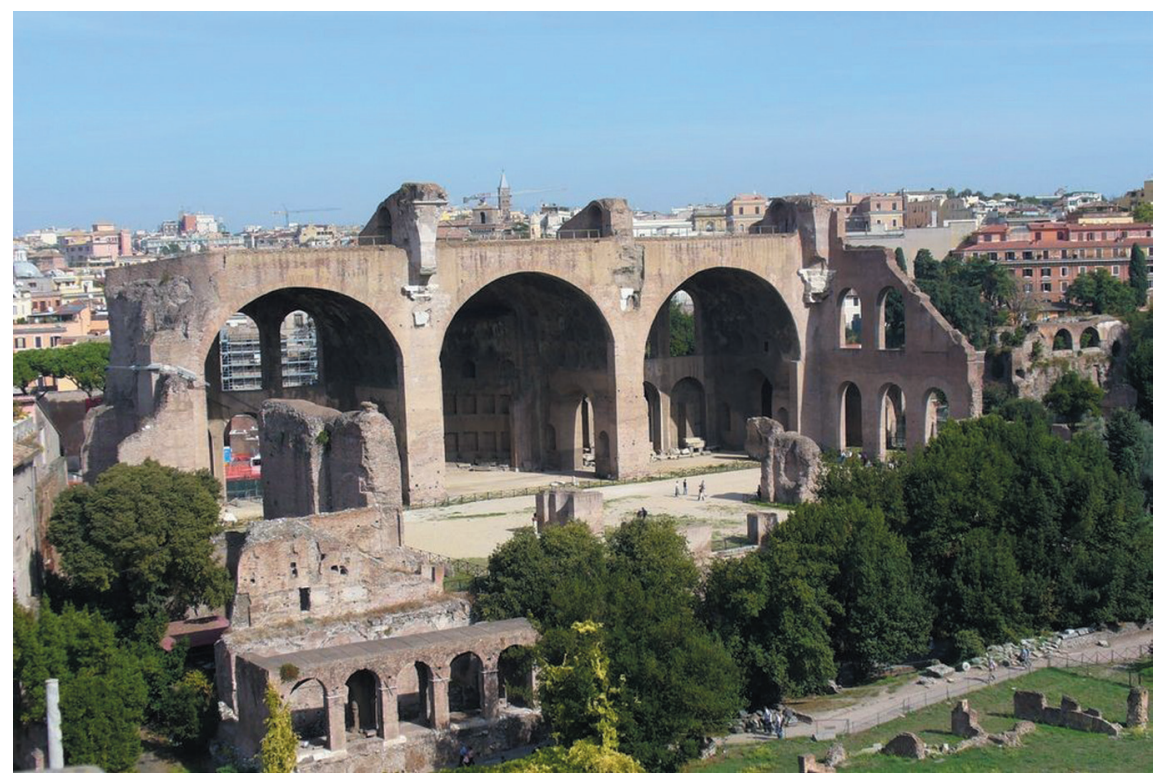

Il. 9. Rzym, bazylika Maksencjusza, ok. 313, ruiny, stan obecny (fot. Z. Kalinowski). 


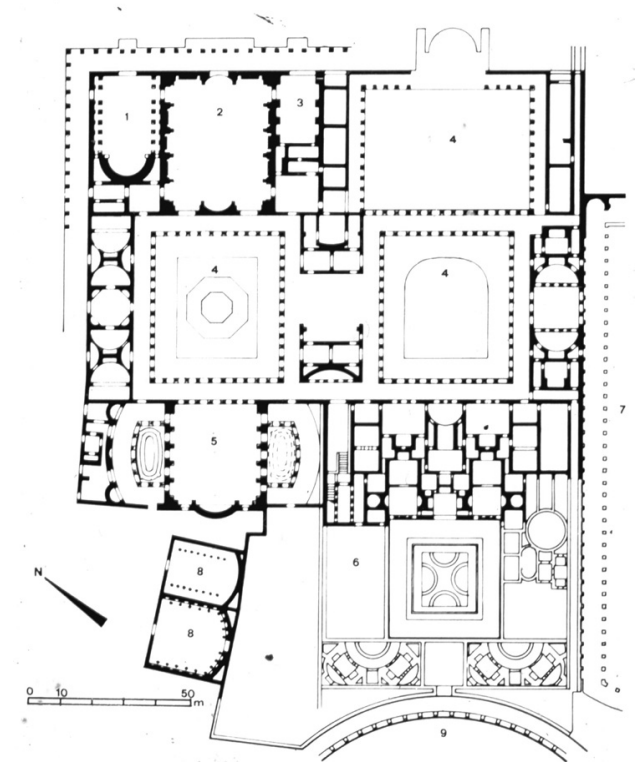

Il. 10. Rzym, zabudowa Palatynu z tzw. pałacem Domicjana (bazylika cesarska oznaczona nr 1) (za: J.B. Ward-Perkins, Roman Architecture, London 1988, fig. 99).

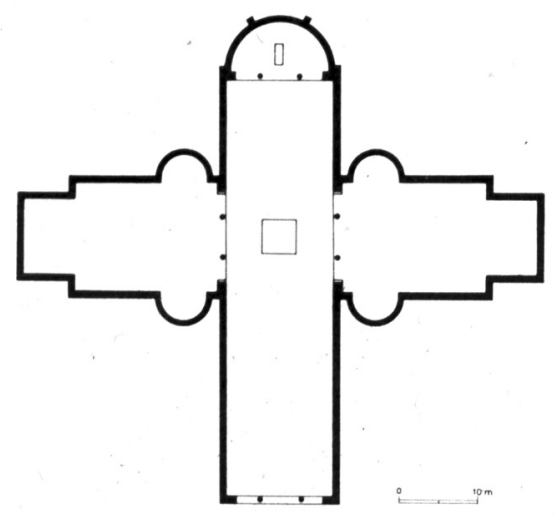

Il. 11. Mediolan, rzut kościoła Apostołów, dziś San Nazaro, 386 r. (za: J. Snyder, Medieval Art. Painting Sculpture Architecture $4^{\text {th }}-14^{\text {th }}$, New York 1989, il. 73). 


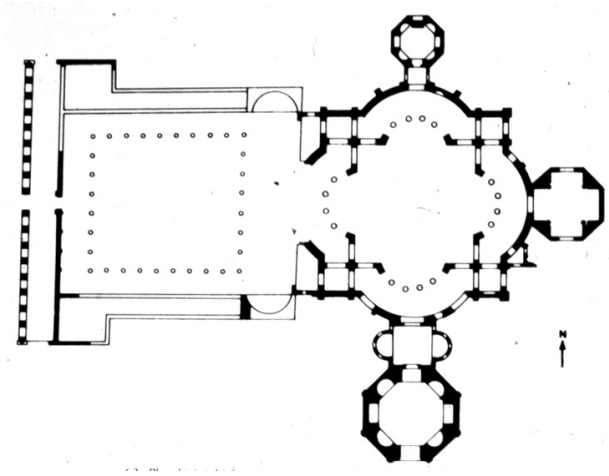

Il. 12. Rzut kościoła San Lorenzo w Mediolanie (za: R. Krautheimer, Early Chrystian and Byzantine Architecture, Harmondsworth 1986, il. 35).

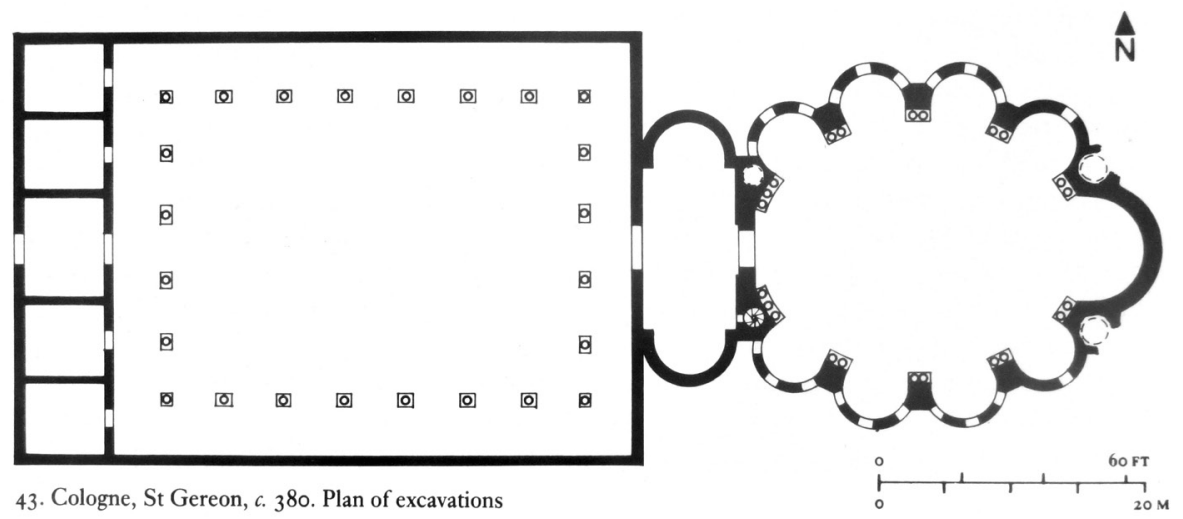

I1. 13. Kościół św. Gereona w Kolonii (za: R. Krautheimer, Early Chrystian and Byzantine Architecture, Harmondsworth 1986, il. 43). 
